\title{
Upaya Guru Pendidikan Agama Islam Dalam Menumbuhkan Kecerdasan Spiritual Siswa
}

\author{
Atika Fitriani, Eka Yanuarti \\ Institut Agama Islam Negeri (IAIN) Curup \\ ekayanuarti14@gmail.com, etikafitriani@gmail.com
}

\begin{abstract}
This research is a qualitative study. The results of this study indicated that: The efforts of teachers in fostering spiritual intelligence of students at SMAN 01 Lebong Atas are carried out in several ways: First, become a rôle modefor their students, second, helping students formulated their life's mission, reciting the Qur'an and explaining its meaning in life, tells students about the great stories of spiritual figures, inviting students to discuss various issues with spiritual perspectives, inviting students to visit people who suffer, engaging students in religious activities, inviting students to enjoy the beauty of nature, engaging students in social activities, and forming a nasyid team.
\end{abstract}

\section{Keywords: Islamic Education Teachers, Spiritual Intelligence}

\begin{abstract}
Abstrak: Penelitian ini bertujuan untuk mengetahui upaya guru pendidikan agama Islam dalam menumbuhkan kecerdasan spiritual siswa di Sekolah. Penelitian ini merupakan penelitian kualitatif. Hasil penelitian ini menunjukkan bahwa: Upaya guru pendidikan agama Islam dalam menumbuhkan kecerdasan spiritual siswa di Sekolah dan dilaksanakan melalui beberapa cara: Menjadi teladan bagi siswanya, membantu siswa merumuskan misi hidup mereka, membaca Al-Qur an bersama siswa dan dijelaskan maknanya dalam kehidupan, menceritakan pada siswa tentang kisah-kisah agung dari tokoh-tokoh spiritual, mengajak siswa berdiskusi dalam berbagai persoalan dengan perspektif ruhaniah, mengajak siswa kunjungan ke tempat-tempat orang yang menderita, melibatkan siswa dalam kegiatan keagamaan, mengajak siswa menikmati keindahan alam, mengikutsertakan siswa dalam kegiatan-kegiatan sosial, dan membentuk tim nasyit.
\end{abstract}

Kata Kunci: Guru Pendidikan Agama Islam, Kecerdasan Spiritual. 


\section{Pendahuluan}

Pendidikan di abad global memanglah sangat kompleks dan heterogen, ditambah lagi dengan lahirnya berbagai macam lembaga pendidikan yang sering kurang memperhatikan atau bahkan mengesampingkan faktor nilai dan agama dalam melaksanakan proses pendidikannya. ${ }^{1}$ Sedangkan pesatnya informasi yang berkembang memegang peranan penting terhadap kualitas hidup seseorang. Harus diingat bahwa kebodohan bukanlah sekedar lawan dari banyaknya pengetahuan, karena bisa saja seseorang memiliki informasi yang banya

$\mathrm{k}$ tetapi apa yang diketahuinya tidak bermanfaat baginya. ${ }^{2}$ Oleh karena itu, tanpa diikuti dengan kematangan intelegensi, emosional, sosial dan akhlak sebagai pedoman pribadi, segala informasi akan dengan mudah diterima oleh seseorang terutama anak-anak sebagai kebenaran yang hakiki.

Terkadang keberhasilan prestasi siswa seringkali diukur dengan nilai raport yang terkesan formalitas. Padahal nilai raport hanya hasil dari kecerdasan intelektual saja, sementara kecerdasan emosional dan kecerdasan sosial kurang mendapat perhatian dalam nilai raport yang selama ini ada. Tentu saja hal ini salah, tetapi tidak benar juga seratus persen, karena berdasarkan penelitian di Harvard University Amerika Serikat ternyata kesuksesan seseorang tidak ditentukan semata-mata oleh pengetahuan dan kemampuan teknis (hard skill) saja, tetapi lebih oleh kemampuan mengelola diri dan orang lain (soft skill) yang lebih berhubungan dengan faktor kecerdasan emosional (EQ). Sedangkan SQ adalah landasan yang diperlukan untuk memfungsikan IQ dan EQ secara efektif. ${ }^{3}$

Dalam rentang waktu dan sejarah yang panjang, manusia pernah sangat menggunakan kemampuan otak dan daya nalar (IQ). Kemampuan berpikir dianggap sebagai primadona, bahkan diklaim sebagai "dewa." Konsekuensinya, potensi diri manusia yang lain dianggap inferior dan bahkan dimarginalkan. Pola pikir dan cara pandang yang demikian telah melahirkan manusia terdidik

${ }^{1}$ Ana Rahmawati, Upaya Guru Pendidikan Agama Islam dalam Mengembangkan Kecerdasan Spiritual pada Siswa di Mi Ma" Arif NU 1 Kalitapen Kec. Purwojati Kab. Banyumas." Skripsi. (Fakultas Tarbiyah dan Ilmu Keguruan IAIN Purwokerto), hlm. 2

2 M. Quraish Shihab, Dia Dimana-mana "Tangan" Tuban dibalik Setiap Fenomena, (Jakarta: Lentera Hati, 2006), hlm. 137

${ }^{3}$ Zubaedi, Desain Pendidikan Karakter (Konsepsi dan Aplikasinya dalam Lembaga Pendidikan), (Jakarta: Kencana, 2011), hlm. 50 
dengan otak yang cerdas, tetapi sikap, perilaku, dan pola hidupnya sangat kontras dengan kemampuan intelektualnya. Banyak orang cerdas secara akademik, tetapi gagal dalam pekerjaan dan kehidupan sosialnya. Mereka memiliki kepribadian yang terbelah (split personality) sehingga tidak terjadi integrasi antara otak dan hati. Kondisi tersebut pada gilirannya menimbulkan krisis multidimensi yang sangat memprihatinkan. ${ }^{4}$

Lemahnya bekal moral keagamaan semacam itu pada gilirannya akan melahirkan individu-individu lemah moral yang kehilangan eksistensitasnya sebagai manusia sejati yang selalu dilandasi oleh semangat kejujuran. Oleh karena itu, upaya pembentukan kepribadian dengan cara menumbuhkan kecerdasan spiritual pada siswa merupakan jalan yang memang harus diterapkan oleh setiap elemen pendidikan saat ini. Pembentukan kepribadian siswa dengan cara menumbuhkan kecerdasan spiritual merupakan pola pendidikan yang harus diterapkan di sekolah, terutama oleh guru Pendidikan Agama Islam. Guru Pendidikan Agama Islam memiliki peranan yang sangat penting dalam menumbuhkan kecerdasan spirtual, disamping lingkungan keluarga yang menjadi lingkungan utama pembentukan kecerdasan spiritual siswa.

Berdasarkan observasi pendahuluan yang peneliti menemukan suatu hal yang menarik, bahwa Sekolah Menengah Atas Negeri 01 Lebong Atas merupakan Sekolah yang mengedepankan dan menanamkan akhlak mulia. Untuk menumbuhkan dan mengembangkan kecerdasan siswa terutama dalam bidang keagamaan adalah hal yang sangat penting terutama di lingkungan sekolah. Pendidikan agama adalah salah satu aspek dasar pendidikan nasional Indonesia yang harus mampu memberikan makna dari hakikat pembangunan nasional. Dan juga mampu menginternalisasikan nilai-nilai dasar yang utuh yang mampu menjadi filter dan selektor, sekaligus penangkal terhadap segala dampak negatif dari dalam proses maupun dari luar proses pembangunan nasional. Semakin bertambah canggihnya teknologi akan mempunyai pengaruh yang sangat besar, jika siswa dibiasakan diajarkan tentang nilai-nilai agama maka akan sangat membantu dalam proses pembentukan perilaku yang berakhlak. ${ }^{6}$

${ }_{9}$ AAbd. Wahab dan Umiarso, Kepemimpinan dan Kecerdasan Spiritual, (Yogyakarta: Ar-Ruzz Media, 2011), hlm. 29

${ }^{5}$ Zubaedi, Op.Cit., hlm. 54

6 Sirajun Nahari (Kepala Sekolah) dan Sri Juda (Guru Pendidikan Agama Islam), Wawancara, tanggal 25 Januari 2017 


\section{Pembahasan}

Dalam Kamus Besar Bahasa Indonesia (KBBI) disebutkan bahwa kecerdasan spiritual adalah kecerdasan yang berkenaan dengan hati dan kepedulian antar sesama manusia, makhluk lain, dan alam sekitar berdasarkan keyakinan akan adanya Tuhan Yang Maha Esa. ${ }^{7}$ Menurut Danah Zohar dan Ian Marshall yang dikutip oleh Ratnawati dan Rini Puspitasari, kecerdasan spiritual yaitu: Kecerdasan untuk menghadapi persoalan makna atau value, yaitu kecerdasan untuk menempatkan perilaku dan hidup kita dalam konteks makna yang lebih luas dan kaya, kecerdasan untuk menilai bahwa tindakan atau jalan hidup seseorang lebih bermakna dibandingkan dengan yang lain. Kecerdasan spiritual adalah landasan yang diperlukan untuk mengfungsikan IQ dan EQ secara efektif. ${ }^{8}$

Menurut Fitri Indriani yang dikutip oleh Yuliyatun menyebutkan agar pemahaman tentang kecerdasan spiritual tidak hanya sampai pada tatanan teoritis saja namun sampai kepraktisnya, maka ada beberapa upaya dan strategi yang harus dilakukan oleh guru pendidi kan agama Islam dalam menumbuhkan kecerdasan spiritual pada siswa antara lain: ${ }^{9}$

1. Menjadi teladan bagi peserta didik.

2. Membantu peserta didik merumuskan misi hidup mereka.

3. Baca Al-Qur’an bersama peserta didik dan jelaskan maknanya dalam kehidupan kita.

4. Menceritakan pada peserta didik tentang kisah-kisah agung dari tokohtokoh spiritual.

5. Mengajak peserta didik berdiskusi dalam berbagai persoalan dengan perspektif ruhaniah.

6. Mengajak peserta didik kunjungan ke tempat-tempat orang yang menderita.

7. Melibatkan peserta didik dalam kegiatan keagamaan.

\footnotetext{
7 Pusat Bahasa Departemen Pendidikan Nasional RI, Kamus Besar Bahasa Indonesia, Edisi Ketiga, (Jakarta: Balai Pustaka, 2005), hlm. 79

8 Ratnawati dan Rini Puspitasari, Psikologi Pendidikan, (Rejang Lebong: LP2 STAIN CURUP, 2013), hlm. 61

9 Yuliyatun, "Mengembangkan Kecerdasan Spiritual Anak Melalui Pendidikan Agama", (Vol.1, 2013) hlm. 168-170
} 
8. Membaca puisi-puisi atau lagu-lagu dan mendengarkan musik yang bersifat spiritual dan inspirasional.

9. Mengajak peserta didik menikmati keindahan alam.

10. Mengikutsertakan peserta didik dalam kegiatan-kegiatan sosial.

Kemudian, tanda-tanda dari kecerdasan spiritual yang telah berkembang dengan baik menurut Zohar dan Marshall yang dikutip oleh Baharudin dan Esa Nur Wahyuni, mencakup hal-hal berikut: ${ }^{10}$

1. Kemampuan bersikap fleksibel (adaptif secara spontan dan aktif).

2. Tingkat kesadaran diri yang tinggi.

3. Kemampuan untuk menghadapi dan memanfaatkan penderitaan.

4. Kemampuan untuk menghadapi dan melampaui rasa sakit.

5. Kualitas hidup yang diilhami oleh visi dan nilai-nilai.

6. Keengganan untuk menyebabkan kerugian yang tidak perlu.

7. Kecenderungan untuk melihat keterkaitan antara berbagai hal (berpandangan holistic).

8. Kecenderungan nyata untuk bertanya "mengapa?" atau "bagaimana jika?" Untuk mencari jawaban-jawaban yang mendasar.

\section{Metodologi Penelitian}

Penelitian ini tergolong penelitian lapangan (field research) apabila dilihat dari tempat penelitian dilakukan. Penelitian lapangan adalah penelitian dengan menggunakan informasi atau responden melalui instrumen pengumpulan data seperti observasi, wawancara, angket dan sebagainya. ${ }^{11}$ Adapun subjek dalam penelitian ini adalah kepala sekolah, guru Pendidikan Agama Islam, dan siswa SMAN 01 Lebong Atas. Sedangkan Objek penelitian ini adalah pembinaan dalam menumbuhkan kecerdasan spiritual siswa. Untuk memperoleh data yang valid maka dalam penelitian ini peneliti menggunakan beberapa teknik pengumpulan data, yaitu Observasi (Pengamatan), wawancara (Interview) dan dokumentasi. Analisis data yang digunakan dalam penelitian ini adalah analisis data kualitatif, dengan analisa non statistik yang tidak dapat diukur dengan angka. Teknik analisa data yang didapat melalui wawancara dideskripsikan secara kualitatif melalui metode deduktif yaitu berpikir dari kesimpulan atau keputusan yang bersifat umum untuk memperoleh kesimpulan atau keputusan yang bersifat

10 Baharudin dan Esa Nur Wahyuni, ... hlm. 163

11 Abudin Nata, Metode Studi Islam, (Jakarta: Raja Grafindo Persada, 2000), hlm. 125 
khusus. Adapun uji keabsahan data dilakukan dengan metode triangulasi. Penelitian ini menggunakan triangulasi sebagai teknik untuk mengecek keabsahan data.

\section{A. Upaya Guru Pendidikan Agama Islam Dalam Menumbuhkan Kecerdasan Spiritual Siswa di SMAN 01 Lebong Atas}

Dalam upaya menciptakan generasi yang memiliki kepribadian yang unggul sangat diperlukan proses pembelajaran yang berkualitas yang tidak hanya diukur pada kapasitas dalam meningkatkan nilai rapor atau peningkatan pada kecerdasan intelektual saja melainkan peningkatan pada kecerdasan spiritual siswa. Hal inilah yang dipahami oleh pihak sekolah SMAN 01 Lebong Atas selama ini. Dalam upaya mewujudkan visi dan misi sekolah dalam menciptakan siswa yang berakhlak maka sekolah harus siap mengfasilitasi siswa dengan instrumen yang mampu disediakan dan dilaksanakan. Sehingga mutu dari proses belajar mengajar yang dilakukan berjalan sesuai dengan koridor yang telah ditetapkan.

Dengan demikian guru dan orang tua diharapkan sekali untuk memahami dan mengetahui manfaat kecerdasan spiritual terhadap siswa, sehingga siswa tidak hanya dituntut untuk mendapatkan nilai yang baik, namun juga siswa disadarkan pada arti sebuah kehidupan yang bermakna melalui kecerdasan spiritual. Dengan kecerdasan spiritual, maka siswa mampu; menjadi kreatif, luwes, berwawasan luas, atau spontan secara kreatif, mengatasi semua masalah tanpa menimbulkan masalah, contoh: sabar, hati-hati dalam mengambil keputusan atau tidak gegabah; selalu jujur dalam bertindak; lebih cerdas secara spiritual dalam beragama; mengedepankan etika dan moral dalam pergaulan; mawas diri, selalu merasa diawasi oleh Allah setiap saat; segala sesuatu yang dikerjakan bernilai ibadah.

Dari banyaknya manfaat kecerdasan spiritual di atas, Kepala SMAN 01 Lebong Atas menerangkan bahwa: ${ }^{12}$

Setiap lembaga pendidikan baik formal, informal maupun nonformal, dalam hal ini orang tua, guru dan siapapun yang terlibat dalam pendidikan tidak hanya mengedepankan kecerdasan intelektualnya saja, namun kecerdasan spiritual juga penting bagi siswa, karena kecerdasan spiritual mampu membawa manusia menuju kesuksesan dunia dan akhirat. Dan dia

12 Sirajun Nahari (Kepala Sekolah), Wawancara, tanggal 20 Mei 2017 
tidak hanya sekedar cerdas dan sadar, tetapi yang lebih penting adalah perilakunya dalam kehidupan sehari-hari baik perilaku individu maupun perilaku sosial.

Sebagaimana yang telah disebutkan dalam teori Fitri Indriani berkaitan tentang upaya dan strategi dalam menumbuhkan kecerdasan spiritual pada siswa agar pemahaman kecerdasan spiritual tidak hanya pada tatanan teori saja namun sampai kepraktisnya sekalipun. Dalam penelitian yang dilakukan menunjukkan bahwa hal tersebut telah dilakukan oleh guru Pendidikan Agama Islam SMAN 01 Lebong Atas dalam menumbuhkan kecerdasan spiritual pada siswanya di sekolah, diantaranya:

\section{Menjadi Teladan Bagi Siswa}

Dalam meningkatkan kecerdasan spiritual siswa, guru hendaknya sudah mengalami kecerdasan spiritual juga. Guru harus bisa memberikan gambaran tentang pentingnya menanamkan kecerdasan spiritual dalam diri seseorang. Hal ini dapat dilakukan oleh guru melalui berbagai cara, baik dalam etika berpakaian, bertutur kata, bersikap, berperilaku, dan lain-lain. Sri Juda (Guru Pendidikan Agama Islam) menjelaskan bahwa: ${ }^{13}$

Setiap guru Pendidikan Agama Islam harus sudah menemukan makna hidupnya dan mengalami hidup yang bermakna, ia tahu kemana harus mengarahkan bahteranya dan ia pun tetap bahagia ditengah ujian dan cobaan yang menghampirinya. Begitupun cara guru dalam mendidik siswanya, harus penuh kesabaran dan ikhlas dalam menghadapi sikap dan perilaku siswanya yang tidak baik. Seorang guru harus bisa memberikan gambaran sikapnya tersebut pada siswanya yang masih dalam taraf pembelajaran mencari jati diri. Kunci dari keberhasilan seorang guru dalam mendidik siswanya terletak pada kemampuan atau keberhasilan guru dalam mentransfer kepribadian yang baik pada siswa dan hal tersebut diterima oleh siswa dengan sepenuhnya.

Kepala sekolah menuturkan bahwa faktor yang paling menentukan mutu pendidikan adalah guru. Kepala Sekolah menilai bahwa guru Pendidikan Agama Islam yakni Ibu Sri Juda adalah sosok guru yang kompeten, bertanggung jawab, terampil, baik, rapi, sopan, dan berdedikasi tinggi. Ibu Sri Juda sangat berkompeten dan bertanggung jawab, utamanya dalam mengawali

${ }^{13}$ Sri Juda (Guru Pendidikan Agama Islam), Wawancara, tanggal 20 Mei 2017 
perkembangan siswa sampai ke suatu titik maksimal. Tujuan akhir seluruh proses pendampingan guru adalah tumbuhnya pribadi dewasa yang utuh. Bila siswa mampu di didik dengan baik sudah barang tentu akan berdampak baik pada kepribadiannya, dan ini akan mempercepat siswa dalam merumuskan tujuan hidupnya. ${ }^{14}$

Berdasarkan pengamatan yang penulis lakukan menunjukkan bahwa guru Pendidikan Agama Islam di SMAN 01 Lebong Atas sangat disukai oleh para siswanya. Karena ia adalah sosok guru yang kompeten, bertanggung jawab, terampil, baik, rapi, sopan, dan berdedikasi tinggi. ${ }^{15} \mathrm{Hal}$ ini terlihat dari perilaku siswa yang sangat sopan dan menghargai gurunya. Hal inilah yang disampaikan oleh Rike Wiranto (Ketua RISMA) bahwa: ${ }^{16}$

Guru Pendidikan Agama Islam di SMAN 01 Lebong Atas sangat baik dan bisa dijadikan tauladan bagi siswa di sekolah ini. Tutur katanya lembut, pakaiannya yang rapi, dan sabar dalam menghadapi tingkah laku siswasiswinya di sekolah. Dan beliau merupakan sosok guru yang saya teladani.

\section{Membantu Siswa Merumuskan Misi Hidup Mereka}

Di SMAN 01 Lebong Atas seorang guru Pendidikan Agama Islam dituntut untuk melakukan pendampingan kepada siswanya dalam memberikan arah dan tujuan hidup mereka. Seperti halnya; membantu siswa dalam mencari jalan untuk meraih kesuksesan di dunia dan di akhirat seperti: Mengarahkan untuk mengerjakan kewajiban shalat, bersedekah, bershalawat, menjauhi pergaulan bebas, narkoba, dan lain-lain. Guru Pendidikan Agama Islam harus selalu menjadi tempat bagi siswa untuk mencari tujuan mereka sebenarnya di dunia dan ke manakah mereka seusai dari kematian mereka, dan apa yang bisa menghantarkan mereka menuju kebahagian dan apa saja yang bisa menghantarkan mereka pada kesengsaraan. ${ }^{17}$

Oleh karena itu dalam proses belajar mengajar, Kepala Sekolah menjelaskan bahwa guru Pendidikan Agama Islam harus bisa menggunakan kesempatan untuk menerangkan pada siswanya melalui diskusi/tatap muka di dalam kelas maupun di luar kelas. Di dalam kelas, guru Pendidikan Agama Islam bisa menyiapkan metode pengajaran yang tepat dengan menyuguhkan matari-

\footnotetext{
${ }^{14}$ Sirajun Nahari (Kepala Sekolah), Wawancara, tanggal 20 Mei 2017

15 Observasi di SMAN 01 Lebong Atas tanggal 13 Mei 2017

${ }^{16}$ Rike Wiranto (Ketua RISMA), Wawancara, tanggal 19 Mei 2017

${ }_{17}$ Observasi di SMAN 01 Lebong Atas tanggal 10-16 Mei 2017
} 
materi yang sesuai dengan jiwa remaja, sehingga pendidikan benar-benar tertanam dan dapat meningkatkan kecerdasan spiritual siswa. Sedangkan di luar kelas, pendampingan bagi siswa dapat dilakukan melalui kegiatan ekstrakulikuler yang diadakan oleh pihak sekolah, seperti kegiatan: RISMA ataupun Keputrian. ${ }^{18}$

Hal tersebut seperti yang telah diungkapkan oleh Sri Juda (Guru Pendidikan Agama Islam): ${ }^{19}$

Dalam memilih metode pengajaran, guru Pendidikan Agama Islam harus mengetahui tujuan apa yang hendak dicapai. Metode yang dipakai harus tepat, artinya materi yang disampaikan sesuai dengan kondisi siswa, dengan kondisi jiwa remaja harus ditonjolkan. Sehingga apa yang kita sampaikan benar-benar tertanam dan dapat meningkatkan pemahaman siswa terhadap pentingnya kecerdasan spiritual bagi siswa. Di sisi lain, seorang guru Pendidikan Agama Islam bisa menggunakan kesempatan pada kegiatan ekstrakulikuler seperti: RISMA atau Keputrian untuk memberi materi tambahan bagi siswa yang ingin belajar tentang keagamaan secara mendalam.

\section{Baca Al-Qur'an Bersama Siswa dan Jelaskan Maknanya dalam Kehidupan Sehari-Hari}

Kepala Sekolah menerangkan bahwa cara ini merupakan pendekatan pengajaran yang sering dilakukan oleh setiap guru Pendidikan Agama Islam tak terkecuali guru Pendidikan Agama Islam di SMAN 01 Lebong Atas. Guru Pendidikan Agama Islam akan selalu mengusahakan siswanya untuk selalu mengamalkan dan selalu dekat dengan kitab suci yakni Al-Qur`an. Al-Qur`an tidak hanya sekedar dibaca, tetapi perlu diberi pemahaman tentang maknanya dan dikaitkan dalam kehidupan. Di SMAN 01 Lebong Atas, rutinitas membaca Al-Qur`an selalu disejajarkan dengan materi isi kultum di setiap hari jumat, dan juga pembiasaan membaca ayat Al-Qur'an secara bersama-sama sebelum memulai pembelajaran, dan ditambah lagi pembiasaan tadarusan sebelum memasuki waktu shalat jumat di masjid "Nurul Iman" SMAN 01 Lebong Atas. ${ }^{20}$

Sri Juda (Guru Pendidikan Agama Islam) menjelaskan bahwa: ${ }^{21}$

\footnotetext{
${ }^{18}$ Sirajun Nahari (Kepala Sekolah), Wawancara, tanggal 20 Mei 2017

${ }^{19}$ Sri Juda (Guru Pendidikan Agama Islam), Wawancara, tanggal 20 Mei 2017

${ }^{20}$ Sirajun Nahari (Kepala Sekolah), Wawancara, tanggal 20 Mei 2017

21 Sri Juda (Guru Pendidikan Agama Islam), Wawancara, tanggal 20 Mei 2017
} 
Pembiasaan membaca Al-Qur`an ini dimaksudkan agar siswa lebih dekat dengan pedoman mereka. Al-Qur an adalah sumber bagi manusia dalam menapaki jalan di dunia ini, jadi bila mereka telah terbiasa membuka AlQur’an dan mengamalkannya, maka dengan itu mereka bisa menjadi pribadi muslim yang baik. Sedangkan bimbingan yang guru berikan bagi siswa di SMAN 01 Lebong Atas termasuk sangat banyak, diantaranya: Kegiatan Risma, dan Kegiatan Keputrian yang sili berganti melakukan bimbingan bagi siswa yang belum fasih membaca Al-Qur`an dan sampai mereka bisa fasih membacanya. Dan sampai saat ini, kegiatan terus dijalankan serta dukungan dari orang tua yang sangat setuju dengan adanya jam tambahan diluar jam sekolah tersebut. Di tambah lagi tidak dipungut biaya sedikit pun, jadi tidak ada alasan untuk menolaknya.

Rita Erlina (Ketua Keputrian) menambahkan bahwa: ${ }^{22}$

Kegiatan membaca Al-Qur`an ini adalah kegiatan rutinitas juga di sekolah kami, kegiatan baca Al-Qur’an biasanya diselaraskan pada kegiatan kultum, sebelum memulai belajar, dan sebelum memasuki waktu shalat jumat bagi laki-laki. Ditambah lagi pembinaan baca Al-Qur`an juga dilakukan pada kegiatan RISMA dan Keputrian.

Berdasarkan pengamatan dilakukan di SMAN 01 Lebong Atas menunjukkan bahwa pembinaan baca Al-Qur’an memang sangat diperhatikan oleh guru Pendidikan Agama Islam. Di tengah sedikit waktu jam belajar siswa di kelas, guru Pendidikan Agama Islam juga melakukan pembinaan baca Al-Qur`an melalui kegiatan ekstrakulikuler seperti: RISMA dan Keputrian. Pembinaan ini juga dibantu oleh rekan-rekan guru yang juga ditunjuk untuk membantu kinerja guru Pendidikan Agama Islam dalam kegiatan tersebut. ${ }^{23}$

\section{Menceritakan pada Siswa tentang Kisah-Kisah Agung dari Tokoh- Tokoh Spiritual}

Upaya yang cukup menarik dalam menumbuhkan kecerdasan spiritual siswa di SMAN 01 Lebong Atas yakni mendongeng/bercerita tentang kisahkisah dari tokoh-tokoh Islami. Komunikasi universal ini dimanfaatkan oleh guru Pendidikan Agama Islam untuk menumbuhkan kecerdasan spiritual siswa

22 Rita Erlina (Ketua Keputrian), Wawancara, tanggal 19 Mei 2017

${ }^{23}$ Observasi di SMAN 01 Lebong Atas tanggal 10-16 Mei 2017 
melalui petikan hikmah jalan hidup seorang tokoh panutan seperti kisah para Nabi dan Rasul, kisah peperangan umat Islam, perjalanan isra " mi" raj Nabi Muhammad SAW, kebesaran tokoh-tokoh kbulafa rasyidin, dan lain-lain. Kesempatan mendongeng ini dilakukan oleh guru Pendidikan Agama Islam disela-sela jam belajar siswa. Metode ini cukup efektif dan keseluruhan siswa menikmati cerita yang disampaikan. Dari kegiatan mendongeng tersebut, guru kemudian akan menguraikan petikan hikmah dan makna dari ceritakan tersebut bagi kehidupan manusia. ${ }^{24}$

Sri Juda (Guru Pendidikan Agama Islam) menjelaskan bahwa: ${ }^{25}$

Tujuan dari kegiatan berceritakan tentang kisah-kisah dari tokoh-tokoh Islam ini ialah untuk memperkenalkan tokoh-tokoh pahlawan Islam kepada siswa. Kebanyakan siswa belum begitu mengetahui secara keseluruhan kisah-kisah pahlawan Islam. Padahal kita tahu bahwa setiap kisah tersebut mengandung nilai riligius yang sangat tinggi lagi bagus bagi kita sebagai umat Islam.

Menumbuhkan spiritual siswa di sekolah ini nampaknya memang merupakan hal yang diutamakan. Berbagai hal diupayakan guru Pendidikan Agama Islam untuk menanamkan nilai-nilai spiritual kepada siswanya. Hal ini diakui oleh Iman Al-Ga Fiqih (Ketua Kelas IPA I) bahwa: ${ }^{26}$

Usaha yang dilakukan oleh guru Pendidikan Agama Islam dalam menumbuhkan spiritual kami sangatlah besar. Tidak cukup dengan berbekal materi pada jam belajar, kegiatan ekstrakulikuler, tetapi juga disaat sela waktu belajar kami pun disering juga diceritakan kisah-kisah pahlawan Islam yang sebelumnya pernah kami dengar dan adapula yang belum kami dengar. Dan kami menikmati semua itu.

Dalam menumbuhkan kecerdasan spiritual siswa diakui oleh Kepala Sekolah memang banyak dibebankan kepada guru Pendidikan Agama Islam. Karena guru Pendidikan Agama Islam lebih mempunyai kemampuan dan pemahaman yang lebih mengenai aspek keagamaan, sedangkan guru-guru lain hanya sekedar membantu saja. Oleh karena itu, dalam upaya menumbuhkan kecerdasan spiritual siswa di sekolah, Kepala Sekolah memberikan keleluasaan

\footnotetext{
24 Observasi di SMAN 01 Lebong Atas tanggal 10-16 Mei 2017

${ }^{25}$ Sri Juda (Guru Pendidikan Agama Islam), Wawancara, tanggal 20 Mei 2017

${ }^{26}$ Iman Al-Ga Fiqih (Ketua Kelas XI IPA I), Wawancara, tanggal 19 Mei 2017
} 
bagi guru Pendidikan Agama Islam untuk menggunakan cara/metode manapun yang ia anggap bisa dilakukan. Pihak sekolah akan membantu dari segi sarana dan prasarana ataupun dalam bentuk yang lain yang mendukung kinerja di lingkungan sekolah. ${ }^{27}$

\section{Mengajak Siswa Berdiskusi dalam Berbagai Persoalan dengan Perspektif Ruhaniah}

Pendekatan yang digunakan ini akan menempatkan siswa untuk lebih peka terhadap kondisi lingkungan sekitarnya. Seperti yang kita ketahui bahwa di wilayah Kabupaten Lebong ini memiliki tradisi adat yang begitu sangat kental, seperti kebiasaan ta"ziah kemakam leluhurnya, melepas ayam kumbang ditempat-tempat yang dikramatkan, menyembelih kambing ditempat kramat, bakar kemenyan dan lain-lain. Ini modal awal guru untuk mendiskusikan dan menerangkan kepada siswa terhadap tradisi yang mereka jalankan tersebut. ${ }^{28}$ Pendekatan ini dinilai efektif untuk memberikan pemahaman kepada siswa untuk lebih bijak dalam menyikapi persoalan tersebut. Agar mereka bisa terhindar dari perbuatan yang terlarang dalam agama yang mereka yakini (Islam).

Sebagaimana dijelaskan oleh Sri Juda (Guru Pendidikan Agama Islam) berikut ini: ${ }^{29}$

Pendekatan ini dilakukan untuk memberikan penjelasan terhadap fenomena yang saat ini masih terus berkembang dilingkungan hidup siswa. Tradisi-tradisi yang terdapat diwilayah mereka nampak sudah menjadi kebiasaan yang terus merisaukan dan tanda tanya bagi siswa, apakah tradisi tersebut menyimpang dari keyakinan mereka? maka dengan adanya kesempatan diskusi ini setidaknya siswa akan lebih leluasa mencurahkan pemikiran dan mendapatkan penerangan yang jelas dari guru agama mereka terhadap peristiwa yang mereka saksikan itu.

Berdasarkan pengamatan yang dilakukan menunjukkan bahwa kegiatan ini memang dilakukan oleh guru Pendidikan Agama Islam bersama dengan para siswanya. Siswa akan diberi keleluasaan untuk bertanya secara langsung kepada guru dan guru akan mendorong para siswa lain untuk memahami, serta bersama

\footnotetext{
${ }^{27}$ Sirajun Nahari (Kepala Sekolah), Wawancara, tanggal 20 Mei 2017

28 Sirajun Nahari (Kepala Sekolah), Wawancara, tanggal 20 Mei 2017

29 Sri Juda (Guru Pendidikan Agama Islam), Wawancara, tanggal 20 Mei 2017
} 
dengan itu memberikan penjelasan secara mendalam kepada siswa agar mengerti. $^{30}$

Dalam sesi wawancara pun siswa juga membenarkan bahwa kegiatan ini sering dilakukan baik itu saat jam belajar ataupun di laur jam belajar. Seperti yang diungkapkan oleh Yoles (Ketua Kelas XI IPS II) berikut ini: ${ }^{31}$

Saya sering sekali bertanya dan mendiskusikan kepada guru Pendidikan Agama Islam tentang pandangan Islam terhadap kegiatan-kegiatan adat yang sering dilakukan oleh masyarakat desa, seperti: Nyembelih hewan di tempat yang di kramatkan, melepas ayam kumbang/putih di kuburan leluhur, bakar kemnyan, dan lain sebagainya. Dan guru Pendidikan Agama Islam sangat senang dengan pertanyaan saya dan kemudian ia akan menerangkan secara rinci tentang hal itu.

\section{Mengajak Siswa Kunjungan ke Tempat-Tempat Orang Sakit dan berta ${ }^{\text {ee }}$ ziah}

Kegiatan mengunjungi orang-orang yang menderita membuat siswa akan tersentuh dan terdorong untuk berbuat baik kepada orang lain. Tempat-tempat yang dimaksud seperti mengunjungi keluarga siswa yang sakit, atau berta ${ }^{\text {ee }}$ ziah ke keluarga siswa yang terkena musibah, dan sebagainya. Dengan melakukan kunjungan seperti ini, diharapkan siswa bisa memaknai dan mensyukuri nikmat yang diberikan oleh Allah SWT kepada mereka. Sehingga nantinya mereka memiliki ketegaran dalam menghadapi masalah-masalah yang bisa datang sewaktu-waktu. ${ }^{32}$

Penanaman nilai keislaman tersebut dilakukan demi meningkatkan rasa kepedulian dan silaturahim antara sesama. Dan pembiasaan keagamaan ini sangat disambut baik oleh seluruh siswa di SMAN 01 Lebong Atas, sebagaimana diungkapkan oleh Dia Try Permata Sari (Ketua OSIS) bahwa: ${ }^{33}$

Kegiatan ini merupakan sebuah kegiatan yang sangat baik, dengannya kami didik untuk menjadi pribadi muslim yang baik, memiliki rasa kepedulian, memupuk hubungan silaturahim antar sesama. Hikmah dibalik kejadian yang kami lihat menjadikan kami manusia yang benar-benar bersyukur atas nikmat yang diberikan oleh Allah SWT, sekaligus

\footnotetext{
${ }^{30}$ Observasi di SMAN 01 Lebong Atas tanggal 10- 16 Mei 2017

31 Yoles (Ketua Kelas XI IPS II), Wawancara, tanggal 19 Mei 2017

32 Sirajun Nahari (Kepala Sekolah), Wawancara, tanggal 20 Mei 2017

33 Dia Try Permata Sari (Ketua Osis), Wawancara, tanggal 19 Mei 2017
} 
memberikan pelajaran bagi kami untuk lebih banyak beribadah, agar menjadi muslim yang dicintai oleh Allah SWT.

Berdasarkan data dokumentasi yang dihimpun menunjukkan bahwa kegiatan tersebut memang dilakukan di SMAN 01 Lebong Atas. Hal ini diharapkan siswa bisa memaknai dan mensyukuri nikmat yang diberikan oleh Allah SWT kepada mereka. Sehingga nantinya mereka memiliki ketegaran dalam menghadapi masalah-masalah yang bisa datang sewaktu-waktu. ${ }^{34}$

\section{Melibatkan Siswa dalam Kegiatan Keagamaan}

Melibatkan siswa dalam setiap kegiatan keagamaan dinilai sangat positif. Siswa akan didorong aktif mengerjakan kegiatan sehingga pekerjaan guru hanya sebagai fasilitator dan memotivator siswa agar lebih disiplin melaksanakan ibadah atau kegiatan-kegiatan keagamaan lainnya. Dengan metode ini, siswa akan mudah dan cepat memahami tujuan dari kegiatan yang dilaksanakan itu, sehingga pembelajaran yang ia dapatkan akan benar-benar tertanam dalam diri siswa. Seperti diungkapkan oleh Dia Try Permata Sari (Ketua Osis) berikut ini: ${ }^{35}$

Dalam setiap kegiatan di sekolah ini, keseluruhannya melibatkan partisipasi seluruh siswa, baik dari segi panitia ataupun pesertanya. Guru hanya sebagai pengarahnya saja yang bekerja tetap siswa yang telah ditunjuk mengatur dan menyiapkan perlengkapan acara.

Kepala SMAN 01 Lebong Atas sangat ketat dan gencar dalam memotivasi siswa dalam kegiatan keagamaan tersebut. Hal ini dapat kita lihat dari ungkapannya yang menyatakan bahwa: ${ }^{36}$

Tugas seorang guru bukan hanya sekedar menjadikan siswa yang cerdas secara IQ, mendapatkan nilai yang tinggi sekolah. Namun seorang guru harus bisa menjadikan siswanya memiliki pribadi yang tangguh; tangguh secara intelektual, tangguh secara emosional, dan paling utama tangguh secara spiritual. Dan inilah arah dan tujuan dari sekolah SMAN 01 Lebong Atas dalam mendidik siswa-siswinya di sekolah.

\footnotetext{
${ }^{34}$ Dokumentasi SMAN 01 Lebong Atas tahun 2015/2016

35 Dia Try Permata Sari (Ketua Osis), Wawancara, tanggal 19 Mei 2017

36 Sirajun Nahari (Kepala Sekolah), Wawancara, tanggal 20 Mei 2017
} 
Ungkapan Kepala SMAN 01 Lebong Atas tersebut dibuktikan dengan banyaknya kegiatan keagamaan yang dilaksanakan. Seperti: bershalawat dan berdoa bersama sebelum dan sesudah belajar, mengucap salam kepada guru ketika memulai dan mengakhiri mata pelajaran, shalat zhuhur berjamaah antara guru dan siswa, shalat dhuha dan acara kultum disetiap hari jumat, menghimpun dana infak, sedekah dari siswa dan dewan guru, shalat jumat berjamaah, acara keputrian, pesantren kilat, mempengirati hari besar Islam, kegiatan risma setiap hari selasa, buka bersama ramadhan, dan lain-lain. Seluruh kegiatan tersebut melibatkan partisipasi siswa. Siswa lebih dipacu dan didorong untuk mengikuti kegiatan tersebut tanpa terkecuali. ${ }^{37}$

\section{Mengikutsertakan Siswa dalam Kegiatan-Kegiatan Sosial}

Kepala Sekolah menjelaskan bahwa kegiatan sosial ini bertujuan agar siswa mengerti sebuah kebersamaan, kesetiakawanan, kepedulian terhadap sesama sebagai makhluk ciptaan-Nya. Misalnya: Anak-anak diajak kerja bakti atau gotong royong, memberi bantuan kepada saudaranya yang tertimpa musibah dan lain-lain. Dengan adanya kegiatan ini maka diharapkan siswa-siswi SMAN 01 Lebong Atas bisa memetik hikmah dibalik kejadian yang terjadi dilihatnya, mengambil pelajaran dan mampu menciptakan kepribadian yang baik sehingga bisa menjadi manusia yang berakblakul karimah. ${ }^{38}$

Sri Juda (Guru Pendidikan Agama Islam) juga menilai bahwa: ${ }^{39}$

Kegiatan ini sangat baik dan bermanfaat. Dulu di Lebong Atas ini jalannya sangat buruk sekali sampai-sampai ada banyak siswa dan masyarakat yang mengalami kecelakaan akibat jalan buruk dan berkerikil. Kemudian Ibu beserta guru-guru yang lain berinisiatif mengadakan kegiatan sosial yakni mengajak siswa gotong-royong membersihkan krikil-krikil yang membahayakan di jalan-jalan khususnya di Lebong Atas. Syukur alhamdulillah siswa sangat antusias melakukannya dan kegiatan berjalan dengan sangat lancar.

Dari data dokumentasi yang dihimpun menunjukkan bahwa kegiatan ini memang dilakukan oleh siswa di SMAN 01 Lebong Atas. Misalnya: Anak-anak

\footnotetext{
${ }^{37}$ Observasi dan Dokumentasi SMAN 01 Lebong Atas tahun 2015-2017

${ }^{38}$ Sirajun Nahari (Kepala Sekolah), Wawancara, tanggal 20 Mei 2017

${ }^{39}$ Sri Juda (Guru Pendidikan Agama Islam), Wawancara, tanggal 20 Mei 2017
} 
diajak kerja bakti atau gotong royong, memberi bantuan kepada saudaranya yang tertimpa musibah dan lain-lain. ${ }^{40}$

\section{Mengajak Siswa Menikmati Keindahan Alam}

Sejauh pengamatan yang dilakukan penulis menunjukkan bahwa kegiatan ini merupakan salah satu pendekatan yang digunakan oleh guru Pendidikan Agama Islam SMAN 01 Lebong Atas dalam menumbuhkan kecerdasan spiritual siswa di luar jam sekolah (kegiatan ekstrakulikuler), seperti pada kegiatan RISMA dan Keputrian. Siswa diajak mengunjungi sebuah tempat yang disesuaikan dengan topik pembahasan dalam kegiatan RISMA atau Keputrian. Dengan adanya kegiatan ini diharapkan siswa lebih memahami tentang Pencipta-nya, dan akan mampu membawa mereka untuk selalu bersyukur atas nikmat dan karunia yang dititipkan oleh Allah SW'T kepada mereka.

Sri Juda (Guru Pendidikan Agama Islam) menerangkan bahwa: ${ }^{41}$

Siswa harus diberi gambaran yang lebih dekat dan itu bisa mereka lihat sendiri terkait tanda-tanda kekuasaan Allah SWT. Dengan hal tersebut diharapkan siswa tersadarkan dan mampu memahami akan keindahan yang mereka nikmati ini merupakan hasil ciptaan Pencipta-nya, maka mereka harus bersyukur dan termotivasi untuk selalu menjalankan perintah-perintah Allah dan menjauhi semua larangan-Nya.

Rita Erlina (Ketua Keputrian) menjelaskan bahwa kegiatan ini sangatlah baik, selain mereka bisa mendapat tambahan ilmu, mereka juga bisa menikmati hasil ciptaan Allah berupa indahnya angin pegunungan, air, hutan, dan lain-lain. Rita juga menyatakan bahwa kegiatan ini merupakan salah satu strategi pembimbing mereka agar siswa semakin bertambah tertarik mengikuti kegiatan tersebut, selain mereka belajar di dalam ruang, mereka bisa juga belajar diruang terbuka sehingga membuat siswa tidak mudah jenuh dalam mengikuti kegiatan tersebut. ${ }^{42}$

Kepala Sekolah pun juga mendukung kegiatan ini, menurutnya kegiatan seperti ini adalah kegiatan yang bagus dan kreatif. Kegiatan ini juga langkah baru yang dilakukan oleh guru Pendidikan Agama Islam dalam mengajarkan siswa di

\footnotetext{
${ }^{40}$ Dokumentasi SMAN 01 Lebong Atas tahun 2016-2017

${ }^{41}$ Sri Juda (Guru Pendidikan Agama Islam), Wawancara, tanggal 20 Mei 2017

${ }^{42}$ Rita Erlina ( Ketua Keputrian), Wawancara, tanggal 19 Mei 2017
} 
luar jam sekolah. Kegiatan ini akan membuat siswa-siswi semangat dan tidak mudah jenuh dalam mengikuti kegiatan-kegiatan ekstrakulikuler, seperti hal kegiatan RISMA dan Keputrian. ${ }^{43}$

\section{Membentuk Tim Nasyit Sekolah}

Siswa biasanya lebih cepat memahami nasihat-nasihat melalui lagu-lagu mengenai ciptaan Allah, tentang alam, hormat kepada orang tua, guru, sayang kepada teman dan lain sebagainya. Dari lagu-lagu tersebut guru ataupun orang tua bisa menjelaskan makna yang terkandung dalam lagu yang baru mereka dengar.

Di SMAN 01 Lebong Atas dapat kita jumpai pada kegiatan RISMA, di mana RISMA ini dimanfaatkan oleh guru untuk membentuk tim nasyit yang beranggotakan siswa-siswi terpilih. Tim nasyit ini digunakan untuk mengisi acara seperti: PHBI baik tingkat sekolah, tingkat kecamatan, kabupaten dan untuk ajang perlombaan tingkat propinsi.

Sirajun Nahari (Kepala Sekolah) mengungkapkan bahwa: ${ }^{44}$

Di bentuknya tim nasyit ini pada awalnya untuk mengisi kegiatan-kegiatan keagamaan di sekolah, namun seiring waktu tim nasyit sekolah ini kemudian banyak digunakan oleh pemerintah daerah untuk memeriahkan kegiatan PHBI Kabupaten Lebong. Oleh karena itu, pihak sekolah mulai mencanangkan bahwa tim nasyit sekolah harus tetap dibina dan tanggung jawab akan dibebankan kepada guru pembimbing RISMA.

Sejauh pengamatan yang dilakukan, penulis membenarkan bahwa kegiatan pembinaan tim nasyit di SMAN 01 Lebong Atas memang benar adanya. Ini dapat dilihat dari adanya tim nasyit dari SMAN 01 Lebong Atas saat ini sering meramaikan kegiatan keagamaan di sekolah maupun diluar sekolah. ${ }^{45} \mathrm{Hal}$ ini juga diakui oleh Rike Wiranto (Ketua RISMA) di bawah ini: ${ }^{46}$

Pembinaan tim nasyit di sekolah ini memang ada dan terus dijalan hingga sekarang. Kami biasanya latihan setiap hari selasa. Dan biasanya kami tampil pada kegiatan-kegiatan keagamaan seperti: Kegiatan PHBI di

\footnotetext{
43 Sirajun Nahari (Kepala Sekolah), Wawancara, tanggal 20 Mei 2017

${ }^{4}$ Sirajun Nahari (Kepala Sekolah), Wawancara, tanggal 20 Mei 2017

45 Observasi dan Dokumentasi SMAN 01 Lebong Atas tahun 2016-2017

46 Rike Wiranto (Ketua RISMA), Wawancara, tanggal 19 Mei 2017
} 
sekolah, Kecamatan, Kabupaten ataupun ajang perlombaan nasyit ditingkat propinsi.

Di samping hal-hal di atas, upaya guru Pendidikan Agama Islam dalam menumbuhkan kecerdasan spiritual siswa di SMAN 01 Lebong Atas juga dapat dilihat melalui berbagai pembiasaan keagamaan yang diadakan di lingkungan sekolah, seperti:

\section{Shalawat dan Berdoa Bersama Sebelum-Sesudah Belajar}

Sebelum pembelajaran dimulai, seluruh siswa akan mengikuti dengan hikmat pembacaan shalawat dan berdoa bersama yang dipimpin oleh salah satu siswa melalui microfon di masjid "Nurul Iman." Ini merupakan pengamalan yang wajib dilakukan di SMAN 01 Lebong Atas.

Sri Juda (Guru Pendidikan Agama Islam) menjelaskan bahwa: ${ }^{47}$

Tujuan dari kegiatan ini adalah sebagai metode pembiasaan, kalau kita teliti bahwa pembiasaan ini sebenarnya berintikan pada pengalaman. Apa yang dibiasakan itu adalah sesuatu yang sering diamalkan dan inti dari kebiasaan itu sendiri adalah pengulangan. Jika setiap hari siswa SMAN 01 Lebong Atas membaca shalawat dan berdoa sebelum mengawali aktivitas belajar khususnya, maka dengan sendirinya para siswa akan terbiasa bershalawat dan berdoa sebelum mengawali segala aktivitas dimanapun siswa berada. Sedangkan seusai kegiatan tersebut dilaksanakan siswa pun akan mengucap syukur "alhamdulillah" atas kenikmatan yang telah dianugerahkan Allah SWT kepada mereka.

Nampaknya guru Pendidikan Agama Islam SMAN 01 Lebong Atas berupaya untuk mendorong siswa agar selalu dekat dengan Pencipta-nya. Hal ini terasa sekali saat sebelum memulai aktivitas belajar mengajar, para siswa di beri waktu duduk dengan rapi sambilan mengikuti shalawat dan doa yang dipimpin oleh temannya melalui mikrofon masjid. Suasana yang riuh menjadi tanpak tenang dengan suara nyaring yang mendendangkan panji-panji Islam yang menenangkan hati sanubari.

Kepala Sekolah pun awalnya sangat menyambut baik ketika pembiasaan bershalawat dan berdoa bersama ini. Dengan diadakannya pembiasaan ini di

${ }^{47}$ Sri Juda (Guru Pendidikan Agama Islam), Wawancara, tanggal 20 Mei 2017 
sekolah diharapkan siswa akan juga terbiasa melakukan dalam keseharian hidupnya. Dan Kepala Sekolah pun selalu mengingatkan dan mengawasi agar pembiasaan ini jangan pernah ditinggalkan. Bahkan setiap paginya siswa selalu diingatkan untuk menyiapkan sounsistem di masjid "Nurul Iman."

\section{Mengucap Salam kepada Guru ketika Memulai dan Mengakhiri Mata Pelajaran}

Pembiasaan yang selalu dijalankan juga oleh setiap siswa di SMAN 01 Lebong Atas ini adalah mengucap salam kepada guru ketika memulai dan mengakhiri mata pelajaran. Dan seluruh siswa nampak mengikuti secara hikmat pembiasaan ini, bahkan dengan semangat mereka ucapkan salam kepada gurugurunya ketika memulai dan mengakhiri mata pelajaran.

Berdasarkan ungkapan Anita Putri (Ketua Kelas XI IPS I) di atas, Kepala sekolah SMAN 01 Lebong Atas membenarkan bahwa pembiasaan tersebut memang dianjurkan oleh pihak sekolah dan wajib hukumnya bagi seluruh siswa. Dan bila terdapat siswa yang tidak melakukan hal tersebut guru bersangkutan di bolehkan memberikan hukuman bagi siswa tersebut, seperti; mengulangi salam sebanyak 10 kali atau di sentrap depan lokal dan lain-lain. Pembiasaan ini merupakan kewajiban muslim yang harus ditunaikan, apalagi siswa di SMAN 01 Lebong Atas saat ini 99.98\% mayoritas muslim. ${ }^{49}$

\section{Mencium tangan ketika berpapasan dengan Guru}

Pembiasaan ini merupakan suatu bentuk sikap menghormati orang lebih tua dari mereka, orang berjasa bagi mereka, dan sikap ini nampaknya diikuti seluruh siswa di SMAN 01 Lebong Atas. Dalam pengamatan yang dilakukan penulis melihat siswa-siswa dengan riang dan sili berganti mencium tangan gurunya.

Pembiasaan ini diakui oleh Rike Wiranto (Ketua RISMA) adalah suatu bentuk penghormatan kepada guru-guru atas jasa telah mengajarkan banyak ilmu kepada mereka. Apalagi didalam kelas guru-guru selalu mengingatkan mereka untuk menghormati orang-orang lebih tua; guru misalnya. Salah satu cara untuk menghormati dan menghargai itu dapat mereka lakukan seperti mencium tangan

\footnotetext{
48 Sirajun Nahari (Kepala Sekolah), Wawancara, tanggal 20 Mei 2017

${ }^{49}$ Sirajun Nahari (Kepala Sekolah), Wawancara, tanggal 20 Mei 2017
} 
guru-gurunya di kala bertemu/berpapasan baik di lingkungan sekolah atau di luar lingkungan sekolah. ${ }^{50}$

Kepala Sekolah menilai bahwa siswa di SMAN 01 Lebong Atas sudah memiliki akhlak yang baik dan itu semua berkat dari guru-guru mereka yang sudah berhasil menanamkan nilai-nilai kepribadian yang baik pada siswa.106 Bentuk kepribadian itu dapat kita lihat sendiri dari kebiasaan siswa dalam keseharian mereka, ketika bertemu/berpapasan dengan guru mereka lalu mencium tangannya. Ia juga mengakui bahwa awalnya kebiasaan ini dilakukan atas kesadaran dari siswa itu sendiri, yang kemudian diikuti siswa-siswa yang lainnya dan seiring waktu menjadi kebiasaan siswa di sekolah ini. ${ }^{51}$

Sri Juda (Guru Pendidikan Agama Islam) mengungkapkan bahwa: ${ }^{52}$

Menanamkan nilai-nilai yang baik kepada siswa adalah suatu kewajiban yang harus dilakukan oleh setiap guru. Guru harus selalu mengingatkan dan mengarahkan siswa untuk selalu melakukan perbuatan-perbuatan yang baik dan sangat mudah dilakukan, seperti: Menghargai guru dengan mencium tangannya dikala bertemu, mengucap salam kepada saudara muslim dan lain-lain. Itu semua hal yang mudah dilakukan siapa saja termasuk siswa SMAN 01 Lebong Atas.

\section{Shalat Zhuhur Berjamaah antara Guru dan Siswa Di Masjid}

Pembiasaan ini merupakan bentuk pengembangan dan peningkatan spiritual siswa kepada Allah SWT. Pembiasaan yang demikian akan menjadikan siswa memiliki kematangan kecerdasan spiritual yang baik, sehingga kebiasaan yang mereka lakukan di sekolah akan diamalkannya dalam kehidupan seharihari. $^{53}$

Dia Try Permata Sari (Ketua OSIS) juga membenarkan bahwa pembiasaan ini memang dijalankan. Dalam pelaksanaannya disesuaikan dengan jadwal yang telah dibuat oleh pihak sekolah. Setiap kelas pasti memiliki giliran shalat zhuhur berjamaah di masjid "Nurul Iman." "54

Sirajun Nahari (Kepala Sekolah) mengungkapkan bahwa: ${ }^{55}$

\footnotetext{
${ }^{50}$ Rike Wiranto (Ketua RISMA), Wawancara, tanggal 19 Mei 2017

51 Sirajun Nahari (Kepala Sekolah), Wawancara, tanggal 20 Mei 2017

52 Sri Juda (Guru Pendidikan Agama Islam), Wawancara, tanggal 20 Mei 2017

${ }^{53}$ Sri Juda (Guru Pendidikan Agama Islam), Wawancara, tanggal 20 Mei 2017.

${ }^{54}$ Dia Try Permata Sari (Ketua Osis), Wawancara, tanggal 19 Mei 2017

55 Sirajun Nahari (Kepala Sekolah), Wawancara, tanggal 20 Mei 2017
} 
Saat ini sangat penting sekali yang namanya kecerdasan spiritual bagi siswa. Bila kita lihat saat ini banyak sekali kasus-kasus yang kita perhatikan di TV dan media, pelanggaran hukum terjadi di mana-mana, seks bebas, narkoba, dan lain-lain sangat mudah didapatkan. Dan saya tidak mau siswa-siswa di SMAN 01 Lebong Atas ini terjebak ke dalam hal tersebut. Segala upaya harus segera di lakukan, salah satu yang anda lihat shalat zhuhur misalnya. Kegiatan ini adalah kegiatan wajib dilaksanakan seluruh siswa, bila kedapatan melanggar atau tidak mengikutinya maka sanksi akan dikenakan. Sanksinya sesuai dengan kesalahan yang dibuat, ada yang di setrap ditengah lapangan bahkan ada yang dikeluarkan dari sekolah. Jadi dalam artian, kegiatan ini bukan main-main dan tidak boleh dilanggar oleh siapapun. Guru-guru juga dituntut berpartisipasi dalam kegiatan ini.

Upaya menumbuhkan kecerdasan spiritual siswa di SMAN 01 Lebong Atas merupakan aspek yang sangat ditonjolkan. Di saat memasuki lingkungan sekolah suasana yang Islami akan begitu sangat kental. Di mana kewajiban menggunakan jilbab bagi wanita bahkan pakaiannya pun menutupi aurat. Ketika waktu shalat zhuhur, adzan dikumandangkan oleh siswa dan kelas yang jadwal shalat zhuhur berduyun-duyun keluar dan segera mengambil air wudhu untuk melaksanakan shalat zhuhur berjamaah.

\section{Shalat Dhuha dan Kultum Setiap Hari Jumat}

Ini adalah kegiatan rutinitas yang dilaksanakan setiap hari jumat pagi di SMAN 01 Lebong Atas, melibatkan siswa tampil sebagai petugas mengisi acara kultum yang terdiri dari; protokol, pemimpin doa, pemimpin shalawat, mengkumandangkan ayat suci Al-Qur`an, penyampai isi kultum. Kegiatan kultum ini dilaksanakan seusai siswa telah mengerjakan shalat dhuha di masjid “Nurul Iman.” Kegiatan ini melibatkan peran aktif siswa, tujuan dari kegiatan ini untuk melatih siswa untuk disiplin, bertanggung jawab terhadap tugas, serta memacu keberanian siswa dan sebagai wadah bagi siswa untuk menampilkan bakat yang mereka miliki dibidang keagamaan. ${ }^{56}$ Kepala Sekolah menerangkan bahwa: ${ }^{57}$

\footnotetext{
${ }^{56}$ Sri Juda (Guru Pendidikan Agama Islam), Wawancara, tanggal 20 Mei 2017

57 Sirajun Nahari (Kepala Sekolah), Wawancara, tanggal 20 Mei 2017
} 
Kegiatan keagamaan seperti ini memang harus dilakukan untuk memacu semangat dan kedisiplinan siswa di sekolah. Melalui kegiatan ini siswa mempunyai wadah yang mampu menunjang pengembangan bakat yang mereka miliki seperti: ceramah agama. Alhamdulillah lewat kebiasaan ini siswa SMAN 01 Lebong Atas sering diminta mengisi ceramah agama di desanya masing-masing.

Berdasarkan observasi yang dilakukan, penulis membenarkan bahwa kegiatan shalat dhuha dan kultum di setiap hari jumat di SMAN 01 Lebong Atas memang dilaksanakan. Bahkan disetiap hari jumat siswa dikhususkan memakai seragam busana muslim lengkap dengan peci bagi laki-laki. Kalau diperhatikan lingkungan sekolah seperti nuansa lingkungan pesantren. Ketika penulis menanyakan kepada siswa bagaimana tanggapan mereka mengenai kebijakan pihak sekolah yang mengadakan kegiatan shalat dhuha dan kultum di setiap hari jumat? seluruh siswa memberi respon yang positif terhadap kegiatan ini. ${ }^{58}$

\section{Menghimpun Dana Infaq, Sedekah dari Siswa dan Dewan Guru Setiap Hari Jumat}

Kegiatan ini biasanya dilakukan oleh siswa dan dewan guru di SMAN 01 Lebong Atas seusai pelaksanaan kegiatan kultum. Kegiatan ini dimaksudkan agar siswa selalu termotivasi melakukan kebajikan seperti bersedekah dan infaq, yang mana dari hal itu akan memberikan faedah/amal bagi mereka. ${ }^{59}$ Subangsi dari dana-dana yang dihimpun tersebut dapat kita lihat dengan didirikan sebuah masjid "Nurul Iman" di lingkungan SMAN 01 Lebong Atas saat ini.

Gerakan menghimpun dana infaq, sedekah dari siswa dan dewan guru adalah awalnya inisiatif yang dilakukan oleh guru Pendidikan Agama Islam yang didukung oleh seluruh elemen sekolah untuk mendorong partisipasi siswa dan guru untuk membantu mewujudkan mendirikan sebuah masjid di lingkungan sekolah. Sehingga nantinya siswa-siswa dan dewan guru bisa shalat dan melaksanakan kewajiban lainnya di masjid tersebut. Melihat wacana yang sangat bagus keseluruhan dewan guru dan siswa antusias berpartisipasi menyumbangkan dan menyisihkan sebagian uang jajannya untuk berinfaq dan bersedekah. Alhasil pada tahun 2010 sebuah masjid didirikan di lingkungan

\footnotetext{
${ }^{58}$ Dia Try Permata Sari (Ketua Osis), W awancara, tanggal 19 Mei 2017

${ }^{59}$ Sirajun Nahari (Kepala Sekolah), Wawancara, tanggal 20 Mei 2017
} 
sekolah dan sampai sekarang masjid itu semakin diperluas dan dirawat dengan baik. $^{60}$

Berdasarkan Observasi yang dilakukan di SMAN 01 Lebong Atas, penulis juga menyaksikan sendiri kegiatan menghimpun dana infaq dan sedekah ini dijalankan. Kegiatan ini dilakukan sehabis pelaksanaan kultum atau sebelum siswa dibubarkan. Masing-masing ketua kelas akan berkeliling menghimpun dana-dana infaq dan sedekah dari teman-temannya yang kemudian diserahkan kepada guru Pendidikan Agama Islam. Setelah itu, salah satu siswa akan mengumumkan kepada siswa jumlah infaq dan sedekah yang terkumpul pada hari ini.

\section{Shalat Jumat Berjamaah “Nurul Iman"SMAN 01 Lebong Atas}

Kegiatan ini merupakan kegiatan rutinitas setiap hari jumat bagi laki-laki. Diadakannya kegiatan ini untuk menumbuhkan spiritual siswa di sekolah, sehingga mereka akan semakin termotivasi belajar agama, karena sekolah telah menyediakan tempat bagi mereka untuk menampilkan hasil penempaan mereka di sekolah, seperti menjadi Imam shalat, khotib, bilal, dan mu ${ }^{\text {ee } a d z i n .}{ }^{61}$

Melalui kegiatan ini, menurut Kepala Sekolah cukup efektif untuk mengembangkan bakat-bakat yang ada didalam diri siswa. ${ }^{62}$ Seperti diketahui bahwa banyak sekali ajang perlombaan keagamaan yang diikuti oleh siswa, alhamdulillah mampu dimenangkan siswa sekolah ini, contohnya: perlombaan sahril Qur`an tingkat Kabupaten juara III, Lomba membaca Al-Qur`an tingkat kecamatan juara I, dan lain-lain. Melihat prestasi yang diukir tersebut nampaknya tidak beralasan bagi sekolah untuk tidak mengembangkan dan mempertahankan sistem yang diterapkan selama ini.

Berdasarkan observasi yang dilakukan, penulis membenarkan bahwa kegiatan shalat berjamaah ini memang dijalankan bahkan petugas-petugas shalat jumat tersebut seluruhnya berasal dari siswa SMAN 01 Lebong Atas. Dalam pelaksanaan shalat jumat ini, dewan guru juga berpartisipasi menjadi jamaah shalat sambilan mengawasi siswa-siswanya di dalam masjid.

\footnotetext{
${ }^{60}$ Sri Juda (Guru Pendidikan Agama Islam), Wawancara, tanggal 20 Mei 2017

${ }^{61}$ Sri Juda (Guru Pendidikan Agama Islam), Wawancara, tanggal 20 Mei 2017

${ }^{62}$ Sirajun Nahari (Kepala Sekolah), Wawancara, tanggal 20 Mei 2017
} 


\section{Kegiatan Keputrian}

Seluruh siswi diwajibkan untuk mengikuti kegiatan ini disela laki-laki menunaikan ibadah shalat jumat berjamaah di masjid "Nurul Iman." Kegiatan ini berisikan pembahasan masalah-masalah keagamaan yang mana tidak mereka dapatkan selama jam belajar di kelas. Jadi, kegiatan ini ditujukan untuk menambah wawasan bagi siswi-siswi SMAN 01 Lebong Atas agar menjadi siswi yang ber-akblakul karimah.

Di akui oleh Ibu Sri Juda bahwa: ${ }^{63}$

Mulanya kegiatan ini ditujukan agar memberikan keseimbangan bagi kegiatan siswa di sekolah. Ketika laki-laki melaksanakan shalat jumat di masjid maka ia mengusulkan agar siswi juga harus diberikan kegiatan tambahan. Oleh karena itu, ia berinisiatif untuk mengadakan kegiatan keputrian bagi siswi-siswi SMAN 01 Lebong Atas. Dalam agenda kegiatan keputrian ini bermacam-macam, dan bahkan setiap topik yang diangkat dalam keputrian akan disesuaikan dengan kondisi yang ada. Bila topiknya tentang ziarah kubur maka siswi-siswi akan diajak kekuburan dan dijelaskan secara rinci maksud dan tujuan ziarah kubur tersebut, begitu juga yang lainnya.

Atas kreativitas guru dalam menyusun agenda kegiatan keputrian tersebut, diakui oleh Rita Erlina (Ketua Keputrian) bahwa seluruh siswi sangat menyambut positif kegiatan ini. Hal ini dikarenakan metode yang digunakan sangat selaras dengan keinginan mereka. Jadi dalam penyampaian materi tidak sekedar teori tetapi siswa akan diajak melihat secara langsung tentang topik yang diangkat dalam kegiatan tersebut. ${ }^{64}$

\section{Kegiatan RISMA}

Setiap hari selasa merupakan kegiatan rutinitas yang dilaksanakan oleh pengurus RISMA SMAN 01 Lebong Atas yang tujuannya untuk meningkatkan pemahaman siswa dalam memperdalam wawasan keagamaan mereka, menempah mental dan mengasah kemampuan keagamaan lebih banyak sehingga bakat-bakat yang mereka semakin matang. Salah satu bentukan dari kegiatan ini ialah terbentuknya tim nasyit sekolah yang pemanfaatan banyak ditujukan dalam

\footnotetext{
${ }^{63}$ Sri Juda (Guru Pendidikan Agama Islam), Wawancara, tanggal 20 Mei 2017

64 Rita Erlina (Ketua Keputrian), Wawancara, tanggal 19 Mei 2017
} 
memeriahkan kegiatan-kegiatan keagamaan baik di sekolah maupun di luar lingkungan sekolah.

Sri Juda (Guru Pendidikan Agama Islam) mengungkapkan bahwa: ${ }^{65}$

Kegiatan RISMA ini ditujukan untuk menambah wawasan siswa mengenai ilmu-ilmu keagamaan seperti: tata cara shalat, taharah, zakat, dan ilmu fikih lainnya. Selain itu, kegiatan RISMA juga mengadakan bimbingan baca Al-Qur`an, serta kegiatan latihan nasyit bagi siswa yang terpilih. Nasyit juga hal pokok yang terus dibina dalam RISMA di bawah pengawasan guru pembimbingnya.

Dengan banyaknya wadah yang menampung siswa dalam belajar agama diakui oleh Rike Wiranto (Ketua RISMA) telah mendorong siswa untuk dengan giatnya belajar agama. ${ }^{66}$

Besarnya pengaruh yang diberikan oleh kegiatan RISMA terhadap tingkat pemahaman siswa terhadap ilmu agama membuat Kepala Sekolah tergerak untuk menyediakan tempat khusus bagi RISMA dalam melaksanakan kegiatan rutinitas di hari selasa tersebut. Kepala Sekolah mengakui kegiatan RISMA ini bisa dijadikan sebagai sarana bagi siswa untuk menambah jam belajar dan mengembangkan bakat mereka seperti dibentuknya tim nasyit sekolah SMAN 01 Lebong Atas. ${ }^{67}$

\section{Memperingati Hari Besar Islam (PHBI)}

Dalam pegelaran PHBI di sekolah, biasanya pihak sekolah pasti mengadakan kegiatan-kegiatan keagamaan seperti pesantren kilat. Kegiatan pesantren kilat ini berisikan kegiatan-kegiatan perlombaan keagamaan, yang pesertanya berasal dari siswa-siswi SMAN 01 Lebong Atas. Adapun cabang lomba tersebut diantaranya: Ceramah agama, tampilan tim nasyit antar kelas, tilatil Qur`an, Azan, busana muslim, dan Puisi. Tujuan diadakannya kegiatan ini untuk memeriahkan PHBI, memupuk semangat siswa dalam menuntut ilmu dengan menyediakan wadah untuk menampilkan hasil dan bakat mereka selama menempah diri di SMAN 01 Lebong Atas. ${ }^{68}$

\footnotetext{
${ }^{65}$ Sri Juda (Guru Pendidikan Agama Islam), Wawancara, tanggal 20 Mei 2017

${ }^{66}$ Rike Wiranto (Ketua RISMA), Wawancara, tanggal 19 Mei 2017

${ }^{67}$ Sirajun Nahari (Kepala Sekolah), Wawancara, tanggal 20 Mei 2017

${ }^{68}$ Sri Juda (Guru Pendidikan Agama Islam), Wawancara, tanggal 20 Mei 2017
} 
Berdasarkan hasil data dokumentasi yang diberikan oleh SMAN 01 Lebong Atas menunjukkan bahwa sesungguhnya kegiatan ini memang telah menjadi kegiatan rutinitas sekolah. Biasanya dalam pelaksanaannya kegiatan pesantren kilat dilakukan 5 hari sebelum hari $\mathrm{H}$. Sedangkan di hari $\mathrm{H}$-nya di isi dengan penyampaian ceramah agama dari ustadz yang memang khusus diundang oleh pihak sekolah.

\section{Buka Bersama Ramadhan}

Biasanya diadakan sebagai bentuk keakraban dan rasa kekeluargaan antar siswa dengan dewan guru di SMAN 01 Lebong Atas. Kegiatan ini merupakan kegiatan rutinitas yang pelaksanaannya dilakukan diawal atau pertengahan bulan ramadhan. Biasanya kegiatan ini juga berisikan ceramah agama yang ditampilkan oleh salah satu siswa sebelum memasuki waktu berbuka. ${ }^{69}$

Sri Juda (Guru Pendidikan Agama Islam) membenarkan bahwa: ${ }^{70}$

Kegiatan ini memang diadakan di SMAN 01 Lebong Atas. Ada banyak manfaat yang bisa diambil dari kegiatan ini, diantaranya: Guru bisa menciptakan hubungan yang harmonis dengan siswa, memupuk tali silaturahim antara siswa dengan guru, meningkatkan spiritual siswa, membentuk perilaku baik pada siswa terhadap guru, teman sejawat dan lingkungan sekitarnya.

Kepala Sekolah membenarkan bahwa kegiatan ini memang sering dilaksanakan, tujuannya untuk memupuk hubungan antara siswa dengan guru dan sekitar lingkungan sekolah. Dan dalam pelaksanaannya pihak sekolah akan memberikan keleluasaan bagi siswa seperti: OSIS, RISMA dan Keputrian untuk menyusun agenda acaranya. ${ }^{71}$

Berdasarkan hasil penelitian di atas dapat dipahami bahwa sepuluh indikator kecerdasan spiritual yang dikemukakan oleh Fitri Indriani yang dikutip oleh Yuliyatun tersebut sudah dijalankan oleh guru Pendidikan Agama Islam SMAN 01 Lebong Atas dalam upaya menumbuhkan kecerdasan spiritual siswa di sekolah meliputi: Menjadi teladan bagi siswa, membantu siswa merumuskan misi hidup mereka, baca al-Qur`an bersama siswa dan jelaskan maknanya dalam kehidupan sehari-hari, menceritakan pada siswa tentang kisah-kisah agung dari

${ }^{69}$ Dia Try Permata Sari (Ketua Osis), Wawancara, tanggal 19 Mei 2017

${ }^{70}$ Sri Juda (Guru Pendidikan Agama Islam), Wawancara, tanggal 20 Mei 2017

${ }^{71}$ Sirajun Nahari (Kepala Sekolah), Wawancara, tanggal 20 Mei 2017 
tokoh-tokoh spiritual, mengajak siswa berdiskusi dalam berbagai persoalan dengan perspektif ruhaniah, mengajak siswa kunjungan ke tempat-tempat orang sakit dan berta"ziah, melibatkan siswa dalam kegiatan keagamaan, mengikutsertakan siswa dalam kegiatan-kegiatan sosial, mengajak siswa menikmati keindahan alam, dan membentuk tim nasyit di sekolah. ${ }^{72}$ Ini merupakan bentuk upaya guru Pendidikan Agama Islam dalam membantu siswa dalam menanamkan nilai-nilai keagamaan yang penting bagi siswa dalam membentuk kepribadian luhur dalam dirinya.

Langkah konkrit dari upaya guru Pendidikan Agama Islam dalam menumbuhkan kecerdasan spiritual siswa di SMAN 01 Lebong Atas tersebut dapat dilihat dari banyaknya kegiatan pembiasaan keagamaan yang dilaksanakan di SMAN 01 Lebong Atas hingga saat ini, diantaranya: Shalawat dan berdoa bersama sebelum-sesudah belajar, mengucap salam kepada guru sebelum memulai dan mengakhiri mata pelajaran, mencium tangan ketika berpapasan dengan guru, shalat zhuhur berjamaah antara guru dan siswa di masjid, shalat dhuha dan kultum setiap hari jumat, menghimpun dana infaq, sedekah dari siswa dan dewan guru setiap hari jumat, shalat jumat berjamaah "Nurul Iman" SMAN 01 Lebong Atas, kegiatan Keputrian, kegiatan RISMA, Memperingati Hari Besar Islam (PHBI), dan buka bersama ramadhan.

Dengan demikian peneliti menilai bahwa upaya guru Pendidikan Agama Islam dalam menumbuhkan kecerdasan spiritual siswa di SMAN 01 Lebong Atas sudah sangat baik. Akses yang memadai dan sarana-prasarana yang mendukung dalam menumbuhkan kecerdasan spiritual di sekolah sungguh memberikan kenyamanan bagi siswa untuk terus menggali dan membina diri agar memiliki kepribadian yang baik serta terhindar dari berbagai perilaku buruk yang malah merugikan diri sendiri seperti: Narkoba, balap liar, pergaulan bebas, dan lain-lain

${ }^{72}$ Yuliyatun, Op.Cit. h. 168-170 


\section{Kesimpulan}

Berdasarkan hasil penelitian di atas, dapat disimpulkan bahwa upaya guru Pendidikan Agama Islam dalam menumbuhkan kecerdasan spiritual siswa di SMAN 01 Lebong Atas memiliki 10 indikator kecerdasan spiritual yang dilaksanakan melalui beberapa cara diantaranya: menjadi teladan bagi siswanya, membantu siswa merumuskan misi hidup mereka, membaca Al-Qur`an bersama siswa dan dijelaskan maknanya, menceritakan pada siswa tentang kisah-kisah agung dari tokoh-tokoh spiritual, mengajak siswa berdiskusi dalam berbagai persoalan dengan perspektif ruhaniah, mengajak siswa kunjungan ke tempattempat orang sakit dan berta" ${ }^{\text {ee }}$ iah, melibatkan siswa dalam kegiatan keagamaan, mengikutsertakan siswa dalam kegiatan-kegiatan sosial, mengajak siswa menikmati keindahan alam, dan membentuk tim nasyit. 


\section{DAFTAR PUSTAKA}

Al-Haitsami, N., 1412 H, Majma" al-Zawaid wa Manba" al-Fawaid, Beirut: Dar alFikr.

Al-Kaaf, A. Z., 2001, Membentuk Akblak Mempersiapkan Generasi Islami, Bandung: CV Pustaka Setia.

Bahri Djamarah Syaiful, 2000, Guru dan Anak Didik dalam Interaksi Edukatif. Jakarta: Rineke Cipta.

Hawi, A., 2008, Dasar-Dasar Pendidikan Islam, Palembang: IAIN Raden Fatah Press.

Ihsan, H. H., 1998, Filsafat Pendidikan Islam, Bandung: CV Pustaka Setia. -, 2007, Filsafat Pendidikan Islam, Bandung: Pustaka Setia.

Moleong, L. J., 2005, Metodologi Penelitian Kualitatif Edisi Revisi, Bandung: Rosdakarya Offset.

Nata, A., 2000, Metode Studi Islam, Jakarta: Raja Grafindo Persada.

Purwanto, M. N., 2003, Ilmu Pendidikan Teoritis dan Praktis, Bandung: Remaja Rosdakarya.

Puspitasari, R. D., 2013, Psikologi Pendidikan, Rejang Lebong: LP2 STAIN CURUP.

Rada, S. d., 2011, Ilmu Pendidikan Islam, Bandung: Alfabeta.

RI, D. A., 2010, Al-Qur an dan Tafsir (Edisi yang Sempurna), Jakarta: Lentera Abadi.

RI, P. B., 2005, Kamus Besar Bahasa Indonesia, Edisi Ketiga, Jakarta: Balai Pustaka.

Rohman, A., 2009, Kapita Selekta Pendidikan, Yogyakarta: Sukses Offiset.

Shihab, M. Q., 2006, Dia Dimana-mana “Tangan” Tuban dibalik Setiap Fenomena, Jakarta: Lentera Hati.

Subagyo, J. P., 2004, Metode Penelitian dalam Teori dan Praktek, Jakarta: Rineka Cipta.

Sudarsono, 2005, Etika Islam tentang Kenakalan Remaja, Jakarta: PT Rineka Cipta.

Sugiono, 2009, Metode Penelitian Kuantitatif Kualitatif dan $\mathrm{R}$ \& D, Bandung: Alfabeta.

Sutejo, M., 1998, Puaduddin Pathal Bapedal, Dirjen Binbaga Islam dan UT.

Suryabrata, S., 1998, Metode Penelitian, Jakarta: Raja Grafindo Persada.

Umiarso, A. W., 2011, Kepemimpinan dan Kecerdasan Spiritual, Yogyakarta: Ar-Ruzz Media.

Wahyuni, B. d., 2008, Teori Belajar dan Pembelajaran, Yogyakarta: Ar-Ruz Media. 
Zubaedi, 2011, Desain Pendidikan Karakter (Konsepsi dan Aplikasinya dalam Lembaga Pendidikan), Jakarta: Kencana.

Ana Rahmawati, 2015, Skripsi: Upaya Guru Pendidikan Agama Islam dalam Mengembangkan Kecerdasan Spiritual pada Siswa di Mi Ma" Arif NU 1 Kalitapen Kec. Purwojati Kabupaten Banyumas, (Fakultas Tarbiyah dan Ilmu Keguruan IAIN Purwokerto).

Muthea Hamidah, 2015, Skripsi: Peran Guru PAI sebagai Motivator dalam Meningkatkan Kecerdasan Spiritual Siswa di SMPN 3 Kedungwaru Tulungagung Tabun, (Jurusan Pendidikan Agama Islam Fakultas Tarbiyah dan Ilmu Keguruan (IAIN) Tulungagung).

Nur Azizah, 2013, Skripsi: Upaya Madrasah dalam Pembinaan Kecerdasan Spiritual Siswa (Studi Kasus di MIN Jejeran Bantul Yogyakarta), (Program Studi Pendidikan Guru Madrasah Ibtidaiyah Fakultas Ilmu Tarbiyah dan Keguruan Universitas Islam Negeri Sunan Kalijaga Yogyakarta ).

Salafudin, 2010, Skripsi: Kecerdasan Spiritual dan Hubungannya dengan Penerapan Nilai-Nilai Kejujuran Siswa MTS Daarul Hikmah Pamulang, (Jurusan Pendidikan Agama Islam Fakultas Ilmu Tarbiyah dan Keguruan Universitas Islam Negeri Syarif Hidayatullah. Jakarta).

Yuliyatun, 2013, Jurnal: Mengembangkan Kecerdasan Spiritual Anak Melahi Pendidikan Agama, Volume 1, Nomor 1, 2017.

Pranala, Kamus Besar Bahasa Indonesia (KBBI) Online, https://kbbi.web.id/menumbuhkan.html, 25 Januari 2017 